Journal of Food Technology and Agroindustry Volume 3 No 1 Februari 2021

P-ISSN: 2656-0623

E-ISSN: 2684-8252

\title{
MINIMALLY PROCESS PADA BUAH RAMBUTAN DAN PERUBAHAN KANDUNGAN VITAMIN C SELAMA PENYIMPANAN BEKU
}

\author{
Rozana $^{1}$, Sunardi $^{2}$ \\ Politeknik Negeri Sambas, Sambas (Indonesia); rozanatunggadewi@gmail.com
}

\begin{abstract}
Fresh-cut rambutan products not only have to look fresh, but must have sensory properties (aroma, taste, texture, and visual appeal) similar to fresh products, they must also be safe, healthy and nutritious. So it is necessary to characterize the quality, especially vitamin $C$ from fresh-cut rambutan products which are vacuum packed and stored at frozen temperatures. The purpose of this study was to determine the effect of frozen storage on changes in vitamin $C$ in minimally processed rambutan. The material used in this study was fresh rambutan fruit, Si Kuning variety, obtained from rambutan collectors in Tengguli Village, Sajad District, Sambas Regency. The fruit used is fruit at the ripe stage. The level of vitamin $C$ at the beginning of storage was $14.0772 \%$. The observed peeled rambutan was stored at -15 oC for 20 days, vacuum packed and without vacuum. The results of testing for vitamin $C$ levels were carried out on the 20 th day of storage. The level of vitamin $C$ of rambutan after 20 days of storage which was stored at -15 oC decreased drastically when compared to the vitamin $C$ content on day 0 . The percentage of loss of vitamin $C$ reached $60 \%$ in vacuum packaged rambutan, and the proportion decreased by $70 \%$ in non-vacuum packed rambutan.
\end{abstract}

Keywords: minimally process, frozen storage, rambutan, vitamin $C$

\begin{abstract}
Produk fresh-cut rambutan tidak hanya harus terlihat segar, tetapi harus memiliki sifat sensori (aroma, rasa, tekstur, dan daya tarik visual) yang mirip seperti produk segarnya, juga harus aman, sehat dan bergizi. Maka perlu dilakukan karakterisasi mutu terutama vitamin $C$ dari produk fresh-cut rambutan yang dikemas secara vacuum dan disimpan pada suhu beku. Tujuan penelitian ini adalah untuk mengetahui pengaruh penyimpanan beku terhadap perubahan vitamin $C$ pada rambutan yang terolah minimal. Bahan yang digunakan pada penelitian ini adalah buah rambutan segar varietas Si Kuning yang diperoleh dari pengepul rambutan di Desa Tengguli Kecamatan Sajad Kabupaten Sambas. Buah yang digunakan adalah buah pada stadia masak. Kadar vitamin C pada awal penyimpanan adalah $14.0772 \%$. Rambutan kupas yang diamati disimpan pada suhu $-15^{\circ} \mathrm{C}$ selama 20 hari, dikemas secara vacuum dan tanpa vacuum. Hasil pengujian kadar vitamin $C$ dilakukan pada penyimpanan hari ke-20. Kadar vitamin $C$ rambutan setelah 20 hari penyimpanan yang disimpan pada suhu $-15^{\circ} \mathrm{C}$ mengalami penurunan secara drastis jika dibandingkan dengan kandungan vitamin $C$ pada hari ke-O. Persentase kehilangan vitamin $C$ mencapai $60 \%$ pada rambutan yang dikemas secara vacuum, dan persentase penurunan sebesar $70 \%$ pada rambutan yang dikemas secara tidak vacuum.
\end{abstract}

Keywords: pengolahan minimal, penyimpanan beku, rambutan, vitamin $C$ 


\section{PENDAHULUAN}

Dorongan masyarakat untuk hidup sehat semakin meningkat dikarenakan semakin meningkatnya kesadaran masyarat tentang gizi dan kesehatan. Pola hidup sehat ini ditunjukkan dengan mengonsumsi makanan yang segar bukan makanan olahan. Salah satu sumber zat gizi terutama vitamin adalah buahbuahan sehingga buah-buahan sangat baik jika dikonsumsi sehari-hari.

Mengonsumsi buah-buahan setiap hari memberikan manfaat positif terhadap kesehatan dan menurunkan kejadian dan kematian akibat gangguan degeneratif, seperti kanker dan penyakit kardiovaskular (Oyebode et al., 2014; Stackelberg et al., 2013, Wang et al., 2014). Banyak penelitian telah menunjukkan bahwa buah-buahan merupakan sumber mikronutrien esensial (seperti vitamin C dan asam folat) dan senyawa bioaktif lainnya, termasuk senyawa fenolik.

Masyarakat perkotaan memiliki kecenderungan pola hidup praktis dalam mengonsumsi suatu produk, menuntut penyajian makanan yang praktis karena waktu untuk penyediaan makanan yang terbatas. Kondisi ini mendorong kemajuan teknologi dalam penyediaan makanan terutama dalam pemilihan sayuran dan buahan siap masak, segar, dan praktis sehingga mudah dan cepat penyajiannya. Peluang menciptakan produk baru untuk menjawab kondisi ini adalah produk buah dan sayur yang diproses secara minimal.

Metode pengolahan pascapanen sangat beragam, termasuk berbagai perlakuan fisik maupun kimia guna meningkatkan umur simpan produk segar. Penggerak produksi pertanian dan industri agribisnis pangan digerakkan oleh permintaan konsumen. Konsumen menuntut variasi makanan yang berkualitas tinggi tanpa mengabaikan aspek keamanan pangan dan juga menuntut agar makanan harus disiapkan dengan cepat dan mudah (Duquesne et al., 2005). Salah satu metode baru dalam memasarkan produk segar adalah buah dan sayur adalah dengan melakukan pengolahan minimal seperti sayuran pra-potong, salad bar yang memberikan kenyamanan bagi konsumen dalam menyajikan buah dan sayur. Beberapa hasil penelitian menunjukkan bahwa operasi pengolahan minimal tidak berdampak signifikan terhadap kualitas nutrisi buah dan sayur.

Produk fresh-cut atau produk terolah minimal adalah produk buah atau sayur yang telah dipangkas (trimming), dikupas (peeled) dan atau dipotong (cut) menjadi produk yang dapat digunakan seluruhnya, kemudian dikemas untuk ditawarkan ke konsumen dengan tetap menjaga kesegaran, tinggi nutrisi, rasa dan citarasa (IFPA, 2004). Peluang pasar untuk pengembangan produk fresh-cut dingin didorong oleh permintaan konsumen akan makanan segar, sehat, enak, dan bebas bahan aditif, aman, dan bergizi.

Buah-buahan tropis fresh-cut yang telah tersedia di pasaran saat ini antara lain melon, semangka, mangga, manggis, nangka, pamelo, pepaya, durian, jeruk bali, nanas, rambutan, campuran buah-buahan. Produk fresh-cut juga tersedia dalam bentuk potongan salad segar yang terdiri dari irisan sayuran berdaun dan campuran salad. Sayuran fresh-cut juag disediakan untuk dimasak seperti wortel kupas/potong, jagung muda, brokoli dan kembang kol, batang saledri potong, kubis parut, asparagus potong, campuran sayur tumis, dan ubi jalar potong. Selain itu juga tersedia secara luas fresh-cut untuk jamu.

Salah satu komoditas hortikultura yang potensial dan banyak mengandung zat gizi dan senyawa antioksidan diantaranya adalah rambutan. Rambutan adalah buah tropis eksotis dari Asia. Buahnya terdiri dari $40 \%$ bagian 
yang dapat dimakan dan $60 \%$ kulit dan biji (Lestari et al., 2014). Daging buah rambutan sangat bergizi dan kaya gula, kandungan vitamin dan mineral (Nath et al., 2009). Perbedaan garis lintang dan lingkungan tumbuh menyebabkan perbedaan pada kandungan gula dan vitamin $\mathrm{C}$, kualitas rasa dan aroma buah.

Seperti halnya buah tropis lainnya, rambutan memiliki umur pascapanen yang pendek dan tanpa penanganan yang benar akan menyebabkan kerusakan lebih cepat setelah dipanen. Pendeknya umur simpan dan sifat produk rambutan yang mudah rusak dapat mengakibatkan kerugian baik bagi petani maupun pedagang buah rambutan.

Peluang perbaikan penanganan pascapanen rambutan sangat dibutuhkan, mengingat buah rambutan merupakan salah satu buah yang memiliki potensi ekspor, meskipun Indonesia belum bisa bersaing dengan negara-negara pengkspor utama seperti Malaysia, Thailand, Philipina, dan Australia. Tujuan ekspor rambutan Indonesia antara lain Amerika Serikat, German, Belanda, Perancis, Arab Saudi, Uni Emirat Arab, Kuwait, Bahrain, Singapura, Qatar, Nederland, dan Taiwan (Margono 2009). Peningkatan volume ekspor rambutan dapat dilakukan jika mampu mempertahankan kesegaran buah rambutan minimal 15 hari untuk tujuan ekspor ke wilayah Timur Tengah (Alfarisi 2016).

Jika umur simpan rambutan dapat diperpanjang hingga beberapa bulan, maka konsumen dapat menikmati buah rambutan diluar musim buahnya. Salah satu teknologi pengawetan yang memungkinkan untuk diaplikasikan adalah pembekuan buah.

Aplikasi proses pembekuan untuk mengingkatkan lama kelangsungan hidup buah telah mendapat perhatian luas karena pembekuan dapat mengurangi air bebas karena pembentukan kristal es dan suhu di bawah $0^{\circ} \mathrm{C}$ menyediakan lingkungan yang mendukung pengurangan reaksi kimia sehingga meningkatkan stabilitas selama penyimpanan (Chaves and Zaritzky, 2018).

Pembekuan dapat diaplikasikan pada buah yang sudah matang sempurna, tidak lunak atau lembek, sudah dilakukan proses pencucian, sortasi, dan menghilangkan bagian yang rusak atau tidak dapat dikonsumsi. Proses pembekuan pada rambutan dapat dikombinasikan dengan teknologi produk terolah minimal atau produk potongan segar (minimally process atau fresh-cut).

Menurut James and Ngarrmsak (2010), peluang pertumbuhan pasar untuk produk fresh-cut akan terus berlanjut jika konsumen percaya bahwa produk fresh-cut aman dan berkualitas tinggi dengan umur simpan yang memadai. Tantangan lain untuk pemasaran produk fresh-cut buah tropis meliputi: (a) Menjaga kualitas produk melalui rantai pemasaran, (b) Sifat mudah rusak pada beberapa jenis buah, (c) Menjaga rantai dingin dan logistik yang tepat, (d) Kecukupan peralatan pemrosesan, penyimpanan berpendingin, dan fasilitas pemrosesan, (e) Ketersediaan teknologi untuk mendirikan pabrik pengolahan dan melakukan penelitian guna mempertahankan mutu produk fresh-cut buah tropis.

Produk fresh-cut tidak hanya harus terlihat segar, tetapi harus memiliki sifat sensori (aroma, rasa, tekstur, dan daya tarik visual) yang mirip seperti produk segarnya, juga harus aman, sehat dan bergizi. Berdasarkan hal tersebut, maka perlu dilakukan karakterisasi mutu terutama vitamin C dari produk fresh-cut rambutan yang dikemas secara vacuum dan disimpan pada suhu beku. Tujuan penelitian ini adalah untuk mengetahui pengaruh penyimpanan beku terhadap perubahan vitamin $\mathrm{C}$ pada rambutan yang terolah minimal.

\section{METODE}

Penelitian dilakukan di Bengkel Produksi Pangan dan Laboratorium Analisis 
Mutu Pangan, Jurusan Agribisnis Politeknik Negeri Sambas. Bahan yang digunakan pada penelitian ini adalah buah rambutan segar varietas $\mathrm{Si}$ Kuning yang diperoleh dari pengepul rambutan di Desa Tengguli Kecamatan Sajad Kabupaten Sambas. Buah yang digunakan adalah buah pada stadia masak. Bahan lain yang digunakan adalah asam sitrat yang digunakan untuk perendaman rambutan yang telah dikupas, plastik Polypropilen untuk mengemas rambutan. Alat yang digunakan adalah pisau untuk mengupas kulit rambutan, timbangan, sealer vacuum, freezer, serta seperangkat peralatan uji vitamin C.

Penelitian dimulai dengan melakukan pengumpulan buah rambutan sesuai varietas yang menjadi objek penelitian, yaitu varietas Si Kuning. Rambutan yang diperoleh dari pengepul di Kecamatan Sajad dibawa ke Bengkel Produksi Pangan untuk dilakukan precooling untuk menghilangkan panas yang terbawa dari lapangan. Rambutan kemudian dicuci sebelum dilakukan pengupasan kulitnya. Setelah dikupas, rambutan direndam selama 1 jam dalam larutan asam sitrat $1 \%$ sebagai antimicrobial agent, kemudian dilakukan pengemasan secara vacuum dan disimpan pada suhu beku $\left(-15{ }^{\circ} \mathrm{C}\right)$. Rambutan disimpan selama 20 hari, kemudian dilakukan pengukuran kadar vitamin $\mathrm{C}$.

Kadar Vitamin C diuji berdasarkan metode AOAC (1984). Daging buah rambutan ditimbang sebnayak 25 gram lalu dihaluskan menggunakan blender. Tambahkan aquades $100 \mathrm{ml}$ untuk melarutkan sampel. Larutan dihomogenkan lalu disaring dengan kertas saring. Tambahkan indikator amilum ke dalam filtrat sampel. Penetapan sampel dilakukan dengan titrasi menggunakan larutan Iodium hingga terjadi perubahan warna menjadi biru tua selama 15 detik. Hasil pengukuran dinyatakan sebagai ml. Penetapan dilakukan sebanyak dua kali (duplo).
$\operatorname{Vitamin} C\left(\frac{m g}{100}\right.$ gram $)=\frac{m L \operatorname{Iod} \times 0.88 \times F P}{m g \text { bahan }} \times 100$

dimana:

mL Iod : volume titrasi

FP : faktor pengenceran

Ws : berat sampel (gram)

\section{HASIL DAN PEMBAHASAN}

\subsection{Rambutan Terolah Minimal (Fresh-cut)}

Menurut International Fresh-Cut

Produce Association (IFPA), produk fresh-cut buah dan sayur didefinisikan sebagai buahbuahan dan sayur-sayuran yang telah dipotong, dikupas atau dipotong menjadi produk yang dapat digunakan $100 \%$, telah dikemas, dan menawarkan kepada konsumen bahwa produk tersebut kaya nutrisi, rasa dan kesegaran yang tetap terjaga (Jideani et al., 2017). Karakteristik utama produk fresh-cut buah dan sayur terletak pada kesegaran, rasa, nutrisi, kualitas sensori, serta umur simpan yang lama (Gonzalez et al., 2004; Smetanska et al., 2013).

Produk fresh-cut dikenal memiliki umur simpan yang lebih pendek dibandingkan dengan buah dan sayuran utuh. Memperpanjang umur simpan produk fresh-cut tergantung pada kombinasi unit operasi serta pengaturan suhu yang tepat selama penyimpanan, penggunaan antibrowning agent, kondisi pengemasan, dan penanganan yang baik (Fonseca et al., 1999; Hernandez et al., 2013). Unit operasi yang diperlukan dalam penanganan dan pemrosesan fresh-cut buah rambutan disajikan pada Gambar 1.

Critical Point pada Proses Produksi Freshcut Buah Rambutan

1. Pemotongan dan Pengupasan (Cutting and Peeling)

Aspek penting dari proses produksi fresh-cut buah rambutan adalah proses pemotongan dan pengupasan. Pemotongan membantu membagi keseluruhan produk buah yang dipanen menjadi bagian kecil sebelum 
Journal of Food Technology and Agroindustry Volume 3 No 1 Februari 2021

P-ISSN: 2656-0623

E-ISSN: 2684-8252

dikemas. Namun akibat dari pemotongan $j$ adalah stress yang melukai jaringan sehingga mempercepat laju pembusukan (Li et al., 2017). Pemotongan meningkatkan laju respirasi (Nobile et al., 2006), menyebabkan perubahan deterioratif yang terkait dengan penuaan jaringan tanaman dan menyebabkan penurunan umur simpan jika dibandingkan produk yang belum diolah (Smetanska et al., 2013).

Selama proses pemotongan, terjadi metabolisme fenolik (reaksi enzimatik oksidatif sehingga memicu pencoklatan

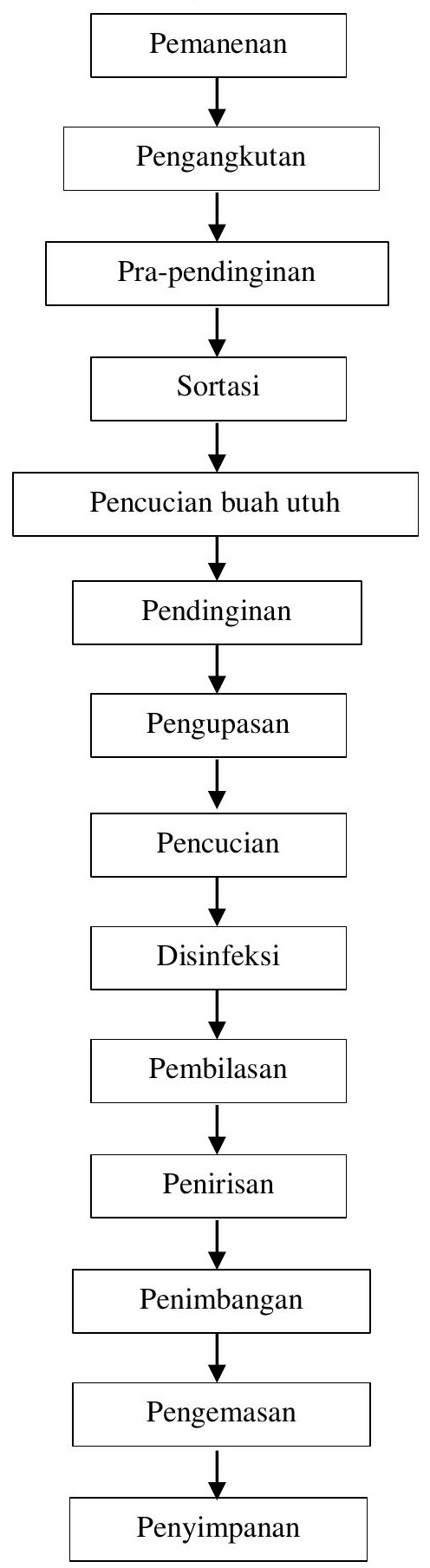

jaringan dan oksidasi polifenol).

\section{Gambar 1. Proses Produksi Fresh-cut Buah} Rambutan

\section{Sanitasi dan Kebersihan pada Fasilitas} Pengolahan

Selama proses produksi, potongan buah terkena mikroba di lingkungan pengolahan. Pengurangan ingkan dan laju kontaminasi sangat bergantung pada penggunaan disinfektan dan pembersih yang sesuai. Salah satu disinfektan yang banyak digunakan pada industri fresh-cut adalah klorin. Namun penggunaan klorin sebagai disinfektan saat ini dilarang di beberapa negara Eropa karena masalah kesehatan.

\section{Penyimpanan (Storage)}

Pembekuan (freezing) adalah proses pengawetan berbagai makanan yang telah dikenal dan diterapkan secara luas, yang menawarkan keuntungan dalam menghasilkan makanan bergizi, berkualitas tinggi dengan umur simpan yang lama. Pembekuan juga telah dinyatakan sebagai salah satu metode terbaik yang digunakan untuk mengawetkan makanan seperti buah dan sayur. Pembekuan fresh-cut buah akan mengurangi pembusukan yang dialama oleh produk (Jideani et al., 2017).

Selama pembekuan, sebagian besar air penyusun bahan makanan berubah menjadi es, sehingga mengurangi aktivitas air, yang memperlambat perubahan fisik dan biokimia yang terlibat dalam kerusakan produk. Buah dan sayur terdiri dari sekitar $85-90 \%$ air, namun mengkristal selama pembekuan. Proses pembekuan mencegah pertumbuhan mikroba, mengurangi aktivitas air, dan mengurangi reaksi kimia dan enzimatik (Anos et al., 2012).

Menurut Jaiswal et al., (2012), penurunan suhu yang dialami selama pembekuan menghambat reaksi metabolisme pada buah dan sayur setelah panen. 
Journal of Food Technology and Agroindustry Volume 3 No 1 Februari 2021

P-ISSN: 2656-0623

E-ISSN: 2684-8252

Pembekuan juga mengurangi laju aktivitas mikrobiologis yang terjadi pada produk freshcut.

\subsection{Vitamin C Fresh-Cut Rambutan}

Sayur dan buah-buahan terutama buah jeruk, sayur berdaun hijau, kembang kol, kubis, tomat, paprika, dan kentang merupakan sumber utama vitamin C (Eitenmiller et al., 2008). Kandungan vitamin $C$ sangat bervariasi antar komoditas yang berbeda. Dengan demikian, tingkat vitamin $\mathrm{C}$ bukan merupakan indikator kualitas itu sendiri, tetapi karena vitamin rentan terhadap oksidasi kimiawi dan enzimatik, dan sangat larut dalam air, maka ini adalah penanda yang sensitif dan tepat untuk memantau perubahan kualitas selama pengangkutan, pemrosesan, dan penyimpanan (Favell, 1998).

Sebelum

dilakukan

proses

penyimpanan, rambutan segar yang digunakan sebagai sampel penelitian ini dilakukan pengujian kadar vitamin C. Hasil pengujian mutu awal rambutan menunjukkan jumlah kandungan vitamin $\mathrm{C}$ pada rambutan $\mathrm{Si}$ Kuning adalah sebesar $14.0772 \%$. Kandungan vitamin C pada rambutan jenis Si Kuning ini memiliki karakteristik yang sama dengan kandungan vitamin $\mathrm{C}$ pada buah Pulasan yaitu sekitar $14-24 \%$ atau rata-rata $18.9 \%$ (Djuita, et al 2017). Namun kandungan vitamin $C$ ini lebih rendah jika dibandingkan dengan kandungan vitamin $\mathrm{C}$ berdasarkan hasil penelitian Johnson, et al (2013) yaitu sebesar $58.29 \mathrm{mg} / 100 \mathrm{~g}(58.29 \%)$.

Kadar vitamin C pada buah rambutan diperoleh melalui pengujian dengan metode Titrasi Iodimetri. Pengujian kadar vitamin C dilakukan pada penyimpanan hari ke-20, dan diperoleh hasil yang disajikan pada Tabel 1.

Tabel 1. Kadar vitamin C rambutan pada penyimpanan hari ke-20

$$
\text { Pengemasan }
$$

Vitamin C (\%)

$$
-15^{\circ} \mathrm{C}
$$

\begin{tabular}{ll}
\hline Vacuum & $5.6315 \%$ \\
Tanpa vacuum & $4.2237 \%$ \\
\hline
\end{tabular}

Tabel 1 menunjukkan bahwa kadar vitamin $\mathrm{C}$ rambutan setelah 20 hari penyimpanan yang disimpan pada suhu $-15{ }^{\circ} \mathrm{C}$ mengalami penurunan secara drastis jika dibandingkan dengan kandungan vitamin $\mathrm{C}$ pada hari ke-0. Persentase kehilangan vitamin C mencapai $60 \%$ pada rambutan yang dikemas secara vacuum, dan persentase penurunan sebesar $70 \%$ pada rambutan yang dikemas secara tidak vacuum.

Vitamin $\mathrm{C}$ dapat mengalami degradasi oksidatif dan enzimatik menjadi asam dehidroaskorbat (DHAA) dan juga oksidasi ireversibel melalui DHAA menjadi asam diketogulonat, dan yang terakhir tidak memiliki aktivitas vitamin C (Nyyssonen et al., 2000). Askorbat oksidase adalah enzim endogen yang terlibat dalam proses tersebut (Saari et al., 1995). Berbagai faktor termasuk keberadaan oksigen dan ion logam (terutama $\left.\mathrm{Cu}^{2+}, \mathrm{Ag}^{+}, \mathrm{Fe}^{3+}\right), \mathrm{pH}$ basa, dan suhu tinggi mempengaruhi kandungan vitamin $\mathrm{C}$ pada produk mentah sebelum dikonsumsi (Lee and Kader, 2000).

Menurut Ileng, et al (2020), pengaruh suhu dingin dan suhu beku memberikan kontribusi terhadap kadar vitamin $\mathrm{C}$ pada buah rambutan yang disimpan pada kemasan terbuka dan tertutup, semakin lama disimpan kadar vitamin $\mathrm{C}$ semakin mengalami penurunan. Menurut Salinas-Roca, et al. (2017), berbagai perlakuan yang diberikan pada rambutan menyebabkan vitamin $\mathrm{C}$ menyusut jika disimpan terlalu lama. Kadar vitamin $\mathrm{C}$ menurun disebabkan oleh degradasi vitamin $\mathrm{C}$, reaksi Mailard dan oksidasi antraquinon (Hamed, et al., 2015).

Penurunan vitamin $\mathrm{C}$ juga terjadi pada raspberry dan blackberry yang disimpan mulai dari 0 sampai 12 bulan. Ditemukan penurunan rata-rata $37 \%$ untuk raspberry dan $31 \%$ untul blackberry (Gonzalez et al., 2003). 


\subsection{Perubahan Warna (Daya Tarik Visual)}

Karakteristik mutu khas pada buah dan sayur dapat dijelaskan oleh empat atribut yang berbeda-beda yaitu: 1) warna dan penampilan, 2) rasa (rasa dan aroma), 3) tekstur, dan 4) nilai gizi. Konsumen biasanya mengevaluasi tampilan visual dan warna terlebih dahulu, diikuti rasa, aroma, dan tekstur.

Penampilan fresh-cut buah rambutan merupakan faktor penentu penerimaan pelanggan, dan sangat mempengaruhi keputusam untuk membeli produk tersebut. Setelah pemrosesan minimal, reaksi metabolisme yang merangsang respirasi dan atau produksi etilen menghasilkan beberapa efek yang tidak diinginkan (perubahan warna, perubahan tekstur, pematangan cepat, dan penuaan) yang dapat mempengaruhi penerimaan konsumen (Velderrain-Rodríguez et al., 2015). Secara khusus, efek pencokelatan dan perubahan warna adalah perubahan yang tidak diinginkan akibatnya mempengaruhi penampilan visual produk segar (Toivonen and Brummel, 2008).

Hasil pengamatan terhadap warna fresh-cut buah rambutan disajikan pada Gambar 2, Gambar 3, Gambar 4.

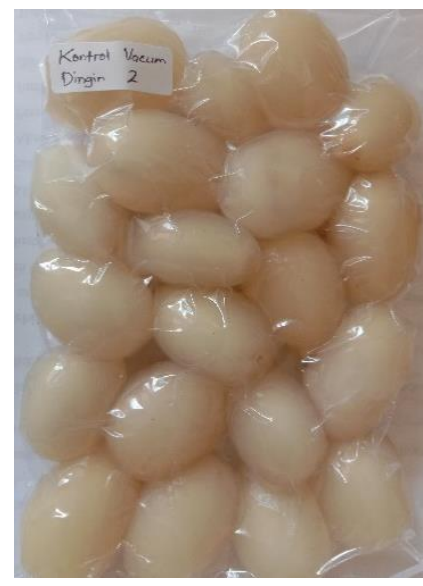

Gambar 2. Rambutan pada Hari Ke-0

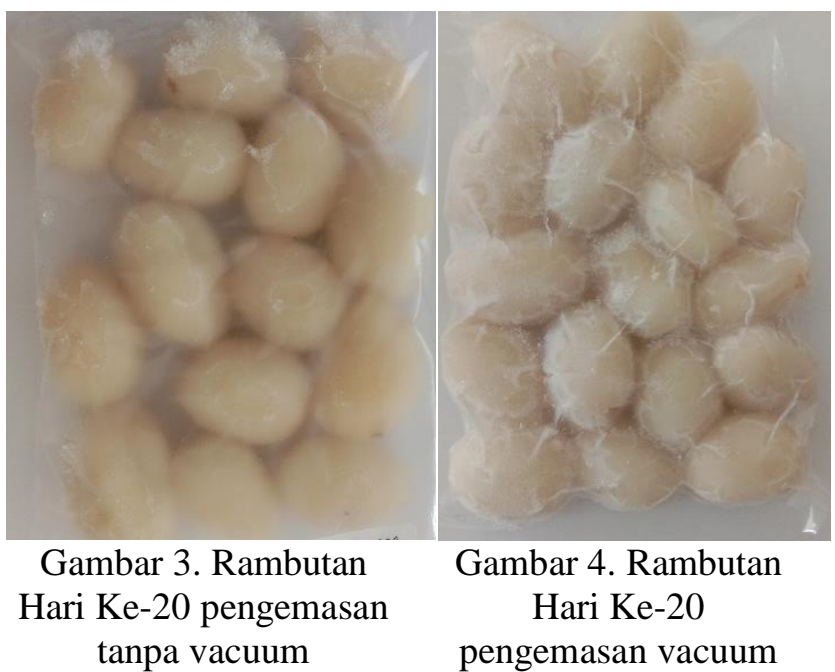

Berdasarkan hasil pengamatan dapat dilihat bahwa proses penyimpanan pada suhu beku hingga hari ke-20 tidak memberikan perubahan warna yang signifikan, hanya terdapat perubahan warna pada pangkal buah yang berubah kecokelatan. Pencokelatan enzimatik pada beberapa produk fresh-cut dimulai dengan gangguan seluler, menyebabkan pelepasan senyawa fenolik yang disimpan dalam vakuola di kompartemen dinding sel. Setelah oksigen menembus jaringan yang terluka, senyawa fenolik menjadi substrat untuk enzim polifenol oksidase (PPO) (Yoruk and Marshall, 2003). Dengan adanya oksigen, PPO dapat mengkatalisasi dua reaksi berbeda: hidroksilasi monofenol dan oksidasi o-difenolsto-kuinon. Setelah o-fenol dioksidasi menjadi o-kuinon, terjadi polimerisasi non enzimatik dari kuinin, mengarah ke pembentukan melanin yang merupakan pigmen dengan massa molekul tinggi dan berwarna gelap (Quieroz et al., 2008).

\section{KESIMPULAN}

Karakteristik utama produk fresh-cut buah dan sayur terletak pada kesegaran, rasa, nutrisi, kualitas sensori, serta umur simpan yang lama. Kandungan vitamin rentan terhadap oksidasi kimiawi dan enzimatik, dan sangat larut dalam air, maka digunakan sebagai 
penanda yang sensitif dan tepat untuk memantau perubahan kualitas selama pengangkutan, pemrosesan, dan penyimpanan. Kadar vitamin $\mathrm{C}$ rambutan setelah 20 hari penyimpanan yang disimpan pada suhu $-15{ }^{\circ} \mathrm{C}$ mengalami penurunan secara drastis jika dibandingkan dengan kandungan vitamin $\mathrm{C}$ pada hari ke-0. Persentase kehilangan vitamin $\mathrm{C}$ mencapai $60 \%$ pada rambutan yang dikemas secara vacuum, dan persentase penurunan sebesar $70 \%$ pada rambutan yang dikemas secara tidak vacuum.Memperpanjang umur simpan produk fresh-cut tergantung pada kombinasi unit operasi serta pengaturan suhu yang tepat selama penyimpanan, penggunaan antibrowning agent, kondisi pengemasan, dan penanganan yang baik.

Kehilangan kandungan nutrisi dalam buah dan sayur merupakan "kerugian tersembunyi" yang dapat terjadi diantara tahap panen dan konsumsi sehingga perlu dioptimalkan pengendalian titik kritis dalam penanganan dan pengolahan.

\section{DAFTAR PUSTAKA}

Alfarisi MW. (2016). Aplikasi Kemasan Vakum dan Pelapisan Lidah Buaya (Aloe vera L.) untuk Mempertahankan Kesegaran Buah Rambutan (Nephelium lappeceum L.). [skripsi]. Bogor (ID): Institut Pertanian Bogor

Artes-Hernandez, P.; Gomez, P.A.; Artes, F. (2013). Unit processing operations in the fresh-cut horticultural products industry: Quality and safety preservation. In: Lima GPP, Vianello F, editors. Food Quality, Safety and Technology. Vienna, Austria: Springer-Verlag. pp. 35-52. DOI: 10.1007/978-3-7091-1640-1_3

Chaves, A.; Zaritzky, N. (2018). Cooling and Freezing of Fruits and Fruit Products. In Fruit Preservation. Food Engineering Series; Rosenthal, A., Deliza, R., WeltiChanes, J., Barbosa-Cánovas, G., Eds.; Springer: New York, NY, USA.

De Anos, B.; Sanchez-Moreno, C.; Pascual-Teresa, S.; Cano, M.P. (2012). Freezing preservation of fruits. In: Sinha N, Sidhu JS, Barta J, Wu JSB, Cano MP, editors. Handbook of Fruits and Fruits Processing. 2ndnd ed. Oxford, UK: John Wiley \& Sons; pp. 103-119

Del Nobile, M.A.; Baiano, A.; Benedeto, A.; Massignan, L. (2006). Respiration rate of minimally processed letuce as affected by packaging. Journal of Food Engineering; 74(1):60-69

Djuita N R, Hartana A, Chikmawati T, Dorly. 2017. Characteristics and Ideotype Formulation of Pulasan (Nephelium ramboutan-ake) Fruit Landrace from West Java, Indonesia. Makara Journal of Science, 21/2, 69-76 doi: 10.7454/mss.v21i2.7304

Duquesne, B.; Mantendo, S.; Lebailly, P.H. (2005). Profiling Food Consumption: Comparison Between USA and EU. Food Consumption Observatory 1-11.

Eitenmiller, R.R.; Ye, L.; Landen Jr.; W.O. (2008). Ascorbic acid: vitamin C. In: Eitenmiller, R.R., Ye, L., Landen, Jr., W.O. (Eds.), Vitamin Analysis for the Health and Food Sciences. 2nd ed. CRC Press, Boca Raton, FL, USA, pp. 231-289.

Favell, D.J. (1998). A comparison of the vitamin C content of fresh and frozen vegetables. Food Chemistry, 62 (1) 5964 ,

Fonseca, S.C.; Oliveira, F.A.R.; Brecht, J.K.; Chau, K.V. (1999) Development of Perforation-Mediated Atmosphere Packaging for Fresh-cut Vegetables. In: Oliveira FAR, Oliveira JC, Hendrickx ME, Korr D, Gorris LGM, editors. Processing Foods: Quality Optimization and Process Assessment. Boca Raton: CRC Press.

Gonzalez-Aguilar, G.A.; Ayala-Zavala, J.F.; Ruiz-Cruz, S.; Acedo-Felix, E; Diaz-Cinco, M.E. (2004). Effect of Temperature and Modifed Atmosphere Packaging on Overall Quality of Fresh-cut Bell Peppers. LWT (8):817826

Hamed S, Zohreh H E, \& Abbasi S. 2015. Effect of Conventional and Ohmic Pasteurizatin on Some Bioactive Components of Aloe vera Gel Juice, Iran J. Chem. Chem. Eng, 34(3): 99-108.

Heriansyah B. 2014. Kombinasi pelapisan lidah buaya (Aloe vera L.) dan void volume kemasan untuk mempertahankan kesegaran buah rambutan (Nephelium lappaceum, Linn.). [Skripsi]. Bogor (ID): Institut Pertanian Bogor

International Fresh-Cut Produce Association (IFPA). (2004). Fresh-Cut Produce/Fresh-Cut Process. International Fresh-Cut Produce Association, USA (www.freshcuts.org).

Jaiswal, A.K.; Gupta, S, Abu-Ghannam, N. (2012). Kinetic evaluation of colour, texture, polyphenols and antioxidant capacity of Irish York cabbage after blanching treatment. Food Chemistry;131:63-72

James, J.B; Ngarmsak, T. (2010). Processing of Fresh-cut Tropical Fruits and Vegetables: A Technical Guide. Food and Agriculture Organization of the United Nations (FAO).

Regional Office for Asia and the Pacific. Bangkok

Jideani, A.I.O.; Anyasi, T.A.; Mchau, G.R.A.; Udoro, E.O.; Onipe, O.O. (2017). Processing and Preservation of Fresh-Cut Frui and Vegetable Products. http://dx.doi.org/10.5772/intechopen.69763

Johnson J.T., Abam K.I., Ujong U. P., Odey M.O., Inekwe V.U., Dasofunjo K., Inah G.M. 2013. Vitamins Composition of Pulp, Seed and Rind of Fresh and Dry Rambutan Nephelium Lappaceum and Squash Cucurbita реро 'L. International Journal of Science and Technology Volume 2 No. 1 , 


\section{Journal of Food Technology and Agroindustry Volume 3 No 1 Februari 2021}

P-ISSN: 2656-0623

E-ISSN: 2684-8252

Lestari S.R.; Djati M.S.; Rudijanto A.; Fatchiyah, F. (2014). The Physiological Response of Obese Rat Model with Rambutan Peel Extract Treatment. J. Asian Pacific Journal of Tropical Disease (4): 780-785

Li, X.; Qinghong Long Q.; Gao F.; Han C.; Jin P.; Zheng Y. (2017). Effect of cuting styles on quality and antioxidant activity in fresh-cut pitaya fruit. Postharvest Biology and Technology (124)1-7.

Nath, V.; Pandey, V.; Pandey, D; Kumar, D. (2009). Rambutan. In: Fruits for the future. Vol.2: Lesser known tropical and subtropical fruits. Published by Satish Serial Publishing House, 403, Express Tower, Commercial Complex, Azadpur, (India).

Oyebode, O.; Gordon-Dseagu, V.; Walker, A.; Mindell, J.S. (2014). Fruit and Vegetable Consumption and All-Caused, Cancer and CVD Mortality: Analysis of Health Survey for England Data. J. Epidemol. Community Health (68): 856862.

Queiroz C, Mendes Lopes ML, Fialho E, Valente-Mesquita VL. (2008). Polyphenol oxidase: characteristics and mechanisms of browning control. Food Rev Int 24(4):361375

Smetanska, I.; Hunaef, D.; Barbosa-Canovas, G.V. (2013). Nonthermal Technologies to extend the Shelf Life of Fresh-cut Fruits and Vegetables. In: Yanniotis S, Taoukis P, Stoforos N, Karathanos VT, editors. Advances in Food Process Engineering Research and Applications, Food Engineering Series. New York, USA: Springer Science + Business Media. pp. 375-413. DOI: 10.1007/978-1-4614-7906-2_18

Stackelberg, O.; Björck, M.; Larsson, S.C.; Orsini, N.; Wolk, A. (2013). Fruit and Vegetable Consumption with Risk of Abdominal Aortic Aneurysm. Circulation (128): 795-802.

Toivonen P, Brummell DA. (2008). Biochemical bases of appearance and texture changes in freshcut fruit and vegetables. Postharvest Biol Technol 48(1):1-14

Velderrain-Rodríguez G, Palafox-Carlos H, Wall-Medrano A, Ayala-Zavala J, Chen CO, RoblesSánchez M, AstiazaranGarcía H, Alvarez-Parrilla E, González-Aguilar G. (2014). Phenolic compounds: their journey after intake. Food Funct 5(2):189-197

Wang, X.; Ouyang, Y.; Liu, J.; Zhu, M.; Zhao, G.; Bao, W.; Hu, F.B. (2014). Fruit and Vegetable Consumption and Mortality from All Causes, Cardiovascular Disease, and Cancer: Systematic Review and Dose-response Metaanalysis of Prospective Cohort Studies. BMJ (349).

Yoruk R, Marshall MR. (2003). Physicochemical properties and function of plant polyphenol oxidase: a review. J Food Biochem 27(5):361-422 